\title{
SELECTED FACTORS RELATED TO THE POTENTIAL FOR CONTAMINATION OF THE PRINCIPAL AQUIFER, SALT LAKE VALLEY, UTAH
}

U.S. GEOLOGICAL SURVEY

Water-Resources Investigations Report 90-4110

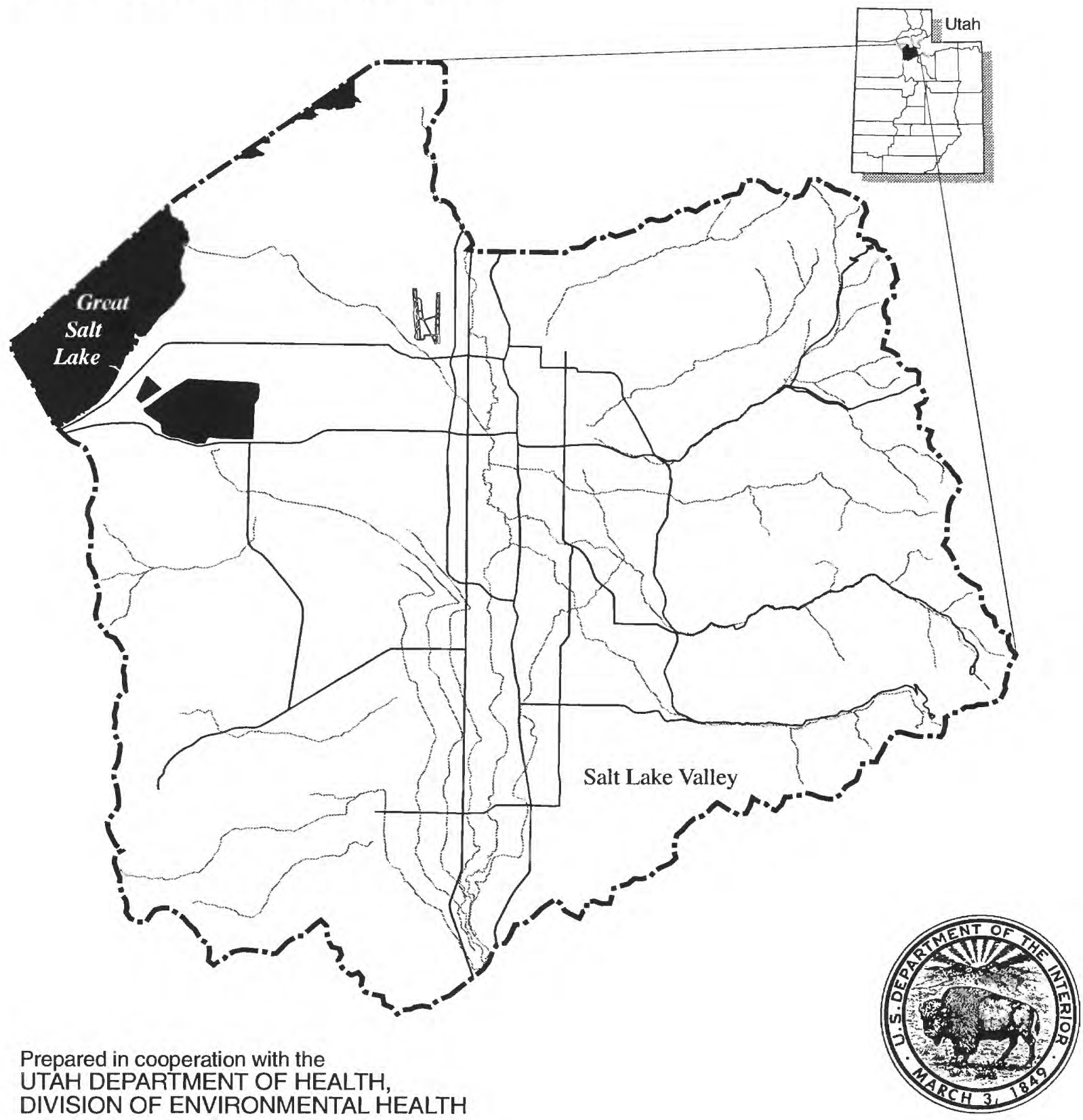




\section{CONTENTS}

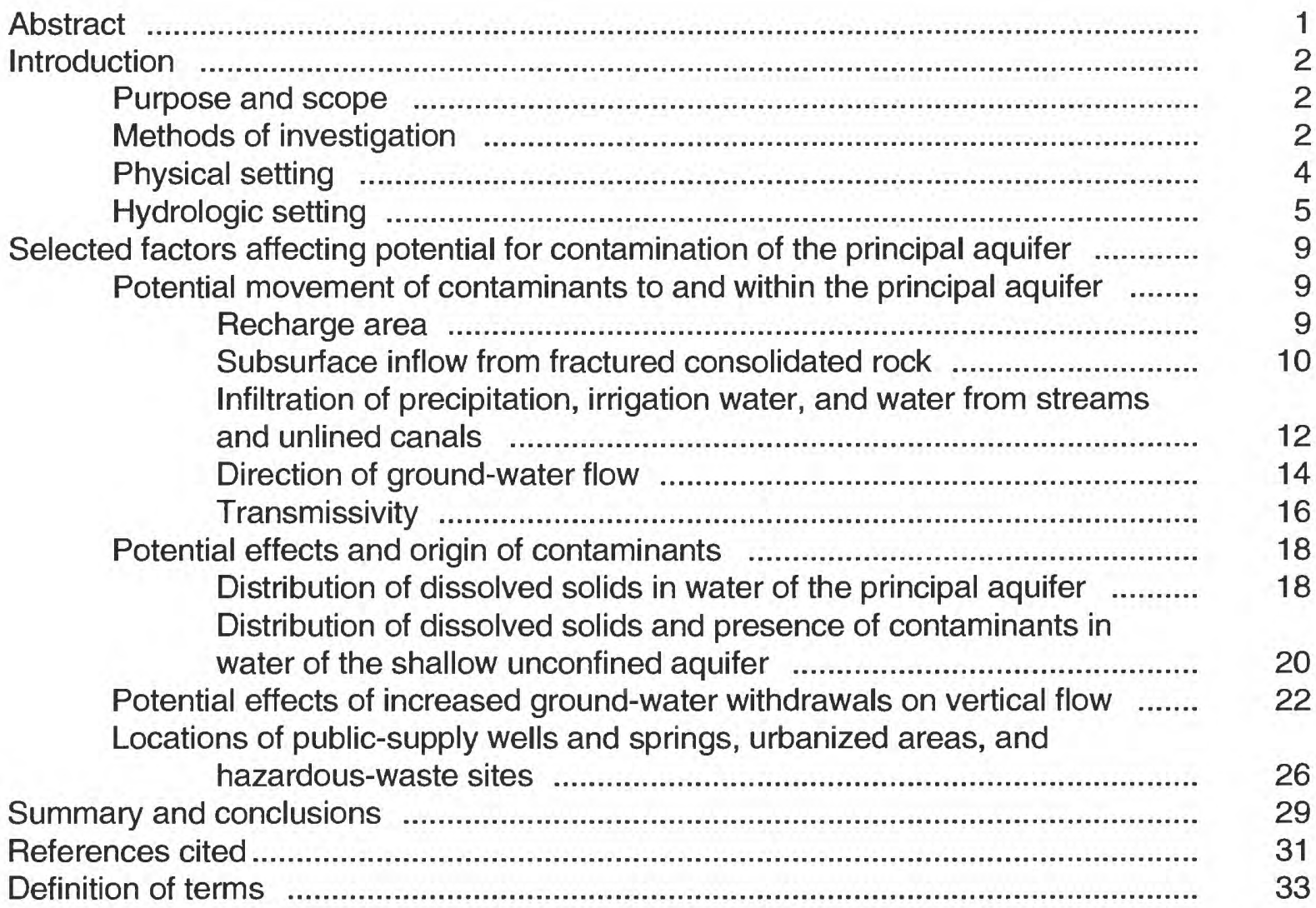




\section{ILLUSTRATIONS}

Plate 1. Generalized area of potential direct recharge, simulated areas of reversal of hydraulic gradient due to ground-water withdrawals from the principal aquifer, and locations of public-supply wells, public-supply springs, and hazardous-waste sites in Salt Lake Valley, Utah

(at back of report)

Figure 1. Map showing location of Salt Lake Valley and approximate

limit of basin fill

2. Generalized block diagram showing part of the hydrogeologic system in Salt Lake Valley

3-12. Maps showing:

3. Areas of subsurface inflow to the principal aquifer from fractured consolidated rock

4. Areas of recharge to the principal aquifer from streams, canals, irrigation, and precipitation

5. General direction of horizontal and vertical ground-water flow in Salt Lake Valley

6. Transmissivity contours used in a digital model of the principal aquifer

7. Distribution of dissolved solids in ground water of the principal aquifer

8. Distribution of dissolved solids in ground water of the shallow-unconfined aquifer

9. Areas where vertical hydraulic gradient could be reversed with a two-fold increase in pumping

10. Areas where vertical hydraulic gradient could be reversed with a three-fold increase in pumping

11. Areas where vertical hydraulic gradient could be reversed with a four-fold increase in pumping

12. Public-supply wells and springs and extent of urbanization in Salt Lake Valley 


\section{CONVERSION FACTORS AND RELATED INFORMATION}

For readers who prefer to use metric units, conversion factors for terms used in this report are listed below:
Multiply
By
To obtain

acre-foot

0
1,233

cubic hectometer

acre-fot

cubic meter

cubic foot per second

0.02832

cubic meter per second

foot

0.3048

meter

foot per day

0.3048

meter per day

mile

1.609

kilometer

foot squared per second

0.0929

meter squared per second

square mile

2.590

square kilometer

Sea level: In this report "sea level" refers to the National Geodetic Vertical Datum of 1929 (NGVD of 1929)--a geodetic datum derived from a general adjustment of the first-order level of both the United States and Canada, formerly called "Sea Level Datum of 1929." 


\title{
SELECTED FACTORS RELATED TO THE POTENTIAL FOR CONTAMINATION OF THE PRINCIPAL AQUIFER, SALT LAKE VALLEY, UTAH
}

\author{
By Robert L. Baskin
}

\begin{abstract}
Selected factors related to potential movement of contaminants to and within the principal aquifer include recharge area and sources of recharge, direction of ground-water flow, and transmissivity. Factors related to potential effects and origin of contaminants include location of highest-quality water in the principal aquifer, location of areas of poor-quality water in the overlying shallow unconfined aquifer, effects of increased groundwater withdrawals on vertical flow, and locations of public-supply wells and springs, urbanized areas, and hazardous-waste sites.

The primary recharge area for the principal aquifer in Salt Lake Valley is along the western edge of the Wasatch Range and the eastern edge of the Oquirrh Mountains. In this area, the principal aquifer is unconfined and is susceptible to movement of contaminants from the land surface to the water table. The primary sources of recharge to the principal aquifer are inflow of water from fractured consolidated rock and seepage from streams emerging from the mountains.

The direction of ground-water flow indicates the path a contaminant would take moving to or within the principal aquifer. Areas where ground-water velocities tend to be large are areas where the potential rate and spread of contamination would be large, and generally coincide with areas of high transmissivity.

Areas where the water in the principal aquifer is of high quality and is used for public supply are areas where contamination would have especially serious consequences. Areas where water in the overlying shallow unconfined aquifer is saline or contaminated by urban activities and where the hydraulic gradient is downward toward the principal aquifer, or where the hydraulic gradient could be reversed from upward to downward by increased pumping, also are areas where water in the principal aquifer is susceptible to contamination. Urbanized areas and locations of hazardous-waste sites are sources of potential contaminants. Where these locations coincide, are in recharge areas, or are near public-supply wells and springs, the principal aquifer is susceptible to contamination and the contamination of the principal aquifer can affect public water supplies.
\end{abstract}




\section{INTRODUCTION}

Salt Lake Valley (fig. 1) has the largest population density in the State of Utah, with about 42 percent $(700,000)$ of the State's people residing in about one percent (780 square miles) of the total area of the State (Utah Office of Planning and Budget, 1987). Ground water provided about 40 percent of the publicwater supply (Johnson and Jackson, 1988) and about 22 percent of the total water use (G.E. Pyper, U.S. Geological Survey, oral commun., 1989) in Salt Lake Valley in 1985. Most ground water used is pumped from the principal aquifer near the center and along the east side of the valley. The main recharge areas for the principal aquifer are at the margins of the valley near the Wasatch Range and the Oquirrh Mountains (pl. 1).

In 1988, the U.S. Geological Survey, in cooperation with the Utah Department of Health, Division of Environmental Health, conducted a study to define-some of the factors related to the potential for contamination of water in the principal aquifer in Salt Lake Valley, Salt Lake County, Utah, an important part of which was defining the aquifer's recharge areas.

Defining the location of natural recharge areas for ground-water reservoirs in Utah is important for urban planning and development, specifically in the potential regulation of land-use activities, so that the recharge process is not adversely affected and the potential for contamination is minimized. Contaminated surface water can be restored to reasonable quality fairly rapidly by decreasing waste loads or concentrations of contaminants entering the water. However, contaminated ground water may be so difficult to restore to its original quality that contamination of aquifers is virtually irreversible once it has occurred (Hem, 1985, p. 203). Leakage of fuels or toxic chemicals from underground storage tanks or surface spills of other contaminants in the recharge areas could result in long-term contamination of the groundwater reservoir.
The Utah Division of Environmental Health wants to identify and characterize areas of natural recharge to the principal aquifer in Salt Lake Valley to provide information to help ensure that land-use activities are managed to minimize the potential for contamination. The lithology and hydrologic properties of the surface and subsurface materials, rate of ground-water movement, and direction of horizontal and vertical hydraulic gradients are important in defining the characteristics of the natural recharge areas for the principal aquifer and areas where contaminants could move rapidly into and within the aquifer.

\section{Purpose and Scope}

This report presents the results of a study to identify some of the factors related to the potential for contamination of the principal aquifer in the Salt Lake Valley. The most important objective of the study was identification of the natural recharge areas for the principal aquifer. The study examined the factors affecting the movement of water from the recharge areas into and within the principal aquifer, and defined areas where increased pumpage of ground water in the confined part of the principal aquifer may cause a downward hydraulic gradient and allow movement of water from the shallow unconfined aquifer to the principal aquifer. Other factors which relate to the origin of potential contaminants and their effects on the water of the principal aquifer, such as concentrations of dissolved solids in ground water and locations of publicsupply wells, public-supply springs, and hazardous-waste sites, also are discussed.

\section{Methods of Investigation}

Hydrologic information for this report was obtained from reports and files of the U.S. Geological Survey and the Utah Division of Environmental Health. Recharge rates, ground-water-flow directions and rates, and transmissivity values were taken from a modular, three-dimensional, finite difference 


\section{EXPLANATION}

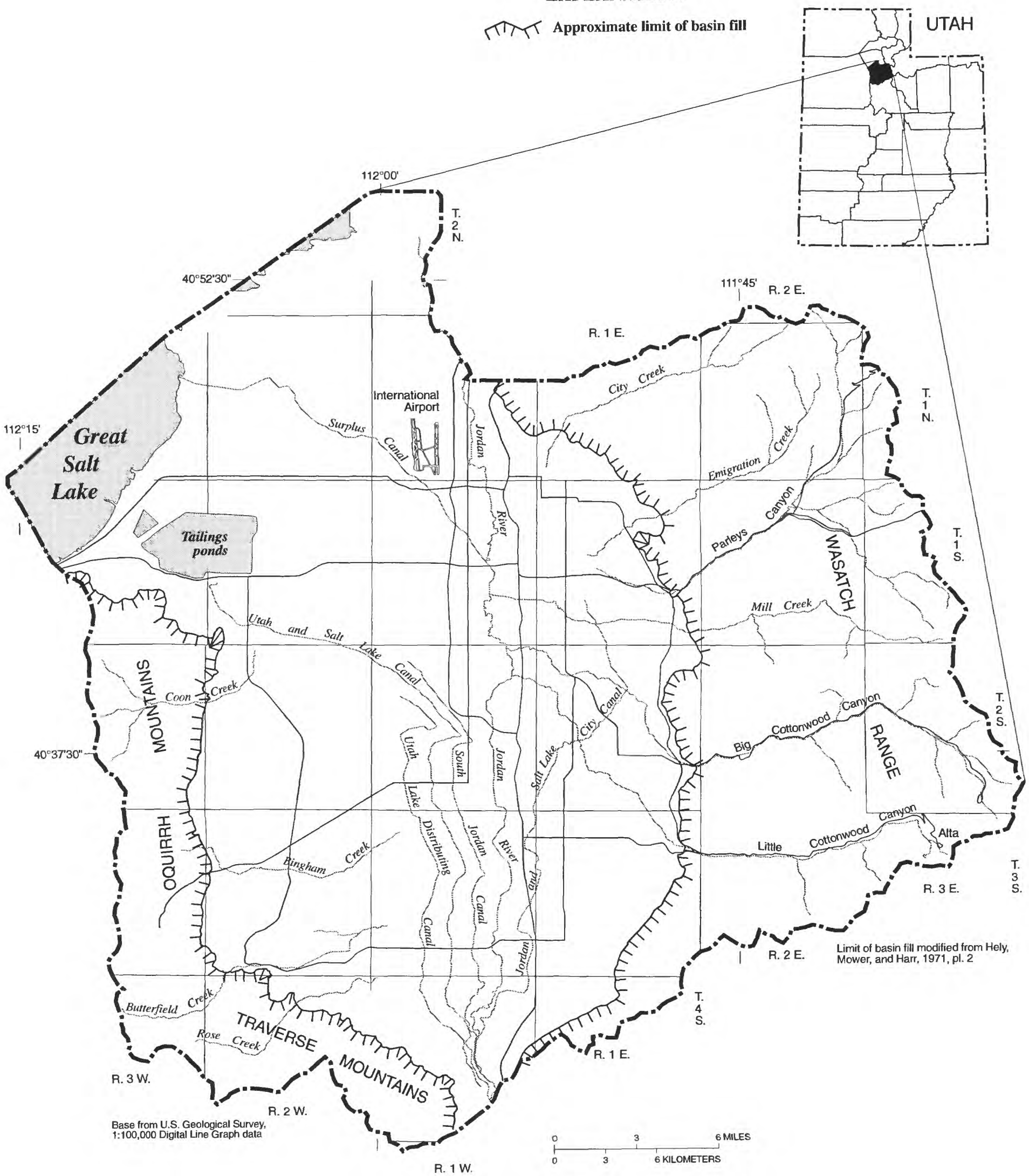

Figure 1. Location of Salt Lake Valley and approximate limit of basin fill. 
ground-water-flow model (McDonald and Harbaugh, 1984) applied to Salt Lake Valley by Waddell and others (1987) and used to simulate the effects of increased or prolonged periods of pumping on water levels and natural discharge. Hydrologic and geologic data for the model came from U.S. Geological Survey groundwater site information (GWSI) files for the years 1969-83, from field measurements made during the study of Waddell and others (1987), and from an electric-analog model of Salt Lake Valley constructed during a study by Hely and others (1971). Some of the illustrations in this report contain information taken directly from simulation results and are intended to show relative locations of recharge and directions of ground-water movement. The areas representing different values for various model parameters on these illustrations have a blocky appearance because of the grid-cell format of the model, and give the false impression that data are not continuous between cells.

A proprietary collection of software called $\mathrm{ARC} / \mathrm{INFO}^{1}$ was used to analyze and display data used in this study. The Environmental Systems Research Institute (ESRI) describes ARC/INFO as "a geographic information system used to automate, manipulate, analyze, and display geographic data in digital form" (ESRI, 1988).

Public-supply well and spring locations were obtained from the files of the Utah Division of Environmental Health and are defined as those wells or springs that are recognized and approved by the Division of Environmental Health, Bureau of Drinking Water/ Sanitation, as a source for a public drinkingwater system. The locations of 181 wells and 18 springs in Salt Lake County were obtained for this study.

1 ARC/INFO is a trademark of Environmental Systems Research Institute, Inc., Redlands, CA. INFO is a trademark of Henco Software, Inc., Waltham, MA. Use of trade names in this report is for identification purposes only and does not constitute endorsement by the U.S. Geological Survey.
The hazardous-waste sites appearing on plate 1 comprise a subset of 86 sites that are included under the Comprehensive Environmental Response, Compensation, and Liability Information System (CERCLIS) for Salt Lake County, current as of June 1988. Sites appearing in CERCLIS satisfy at least one of two criteria: (1) A suspected or known release of hazardous waste [as defined under the Resource Conservation and Recovery Act (RCRA)] has occurred at the site; or (2) a release of a reportable quantity of hazardous substance [as defined in the Comprehensive Environmental Response, Compensation, and Liability Act (CERCLA)] has occurred. The CERCLIS list was used to identify all sites where a release of hazardous waste or hazardous substance to the environment has occurred. The list may contain some sites that have no effect on the quality of ground water, such as a discharge to the atmosphere.

Land use in 1979 for Salt Lake County was classified by the University of Utah Research Institute (1982) from aerial photographs. Land use was categorized into 8 primary groups and 41 secondary groups. For the purposes of this report, land use was generalized into three main classes; urban residential, urban-commercial/industrial, and other. Areas with a perimeter of less than 100 square meters were not included in the landuse classification for this report. These areas were primarily small ponds or waterbodies.

\section{Physical Setting}

Salt Lake Valley is in the center of Salt Lake County at the eastern edge of the Basin and Range physiographic province (Fenneman, 1931). The valley encompasses about 500 square miles and is bounded by the Wasatch Range to the east, Great Salt Lake to the northwest, the Oquirrh Mountains to the west, and the Traverse Mountains to the south (fig. 1). Elevations in the valley range from about 4,200 feet above sea level at Great Salt Lake to about 5,200 feet above sea level at the valley's eastern edge. The mountains to the west of Salt Lake Valley rise 
to elevations of about 9,000 feet, and to the east rise to about 11,000 feet.

The basin-fill deposits of Salt Lake Valley are generally unconsolidated, but in some places at depth, are semiconsolidated. Rocks that underlie the basin fill at depths ranging from several hundred to several thousand feet, and that make up the adjacent mountains, are consolidated. The basin-fill deposits are a complex series of lake, mudrock flow, alluvial-fan, sand-dune, glacial, and floodplain sediments, ash falls, and lava flows (Hely and others, 1971, p. 11). Large alluvial fans were deposited at the foot of the mountains to the center of the valley. Because of the depositional history of the valley, deposits at land surface may not resemble those at depth. Coarse-grained sediments generally are found near the mountain fronts where the sudden widening of stream channels and decrease in slope results in decreased stream velocities, decreasing the capacity of the streams to carry larger fragments of rock.

The Wasatch Range and the Oquirrh Mountains are composed of consolidated rock with little primary porosity. However, faults, joints, and solution openings are common near the land surface and are believed to exist at depth, creating secondary porosity which is important in the subsurface movement of ground water. Detailed descriptions of the surficial geology along the Wasatch Range are found in a report by Miller (1980), and information for the Oquirrh Mountains is described by both Gilluly (1932) and Cook (1961).

\section{Hydrologic Setting}

The climate in Salt Lake County ranges from semiarid in the valley to humid in the mountains east of the valley. Normal annual precipitation ranges from an average of about 15 inches at the Salt Lake City Weather Service Forecast Office, located adjacent to the Salt Lake International Airport (National Oceanic and Atmospheric Administration, 1982), to 57 inches in the mountains at Alta (fig.
1)(Brough and others, 1983). In Salt Lake Valley, the months with the greatest precipitation, which may fall as either rain or snow, are March and April; most precipitation in the mountains falls as snow during the late fall to early spring months (October through April) (Brough and others,1983).

As the snow in the mountains melts during the spring, a large quantity of freshwater runoff becomes available for recharge. Extensive deposits of permeable material along the mountain fronts allow rapid infiltration and percolation of water into the underlying basin-fill deposits. The quantity of snowmelt that infiltrates into the ground rather than running off depends to a large extent on the type and hydraulic conductivity of the rocks, soils, and sediments exposed at the surface. In areas where the surface material has a large hydraulic conductivity, much of the available water may infiltrate rather than run off. In areas of small hydraulic conductivity, the opposite may be true.

The aquifer system in the basin fill of Salt Lake Valley is complex, but has been idealized as consisting of a principal aquifer, a series of confining beds, and the shallow unconfined aquifer (fig. 2). The principal aquifer is unconfined at the mountain fronts but becomes confined or semiconfined by finegrained sediments overlying the aquifer toward the center of the valley. The shallow unconfined aquifer overlies the fine-grained confining beds (fig. 2). This idealized division of the aquifer system does not occur everywhere in the Valley. The principal aquifer is the main source of ground water for public supply, industry, and irrigation in Salt Lake Valley. Water in the shallow unconfined aquifer is little used.

As ground water moves from the recharge areas near the mountain fronts toward areas of natural discharge in the center or northwest part of the valley, fine-grained sediments above the principal aquifer retard the upward movement of water. In much of this part of the valley, the hydraulic head for the principal aquifer is higher than the top of the confining 


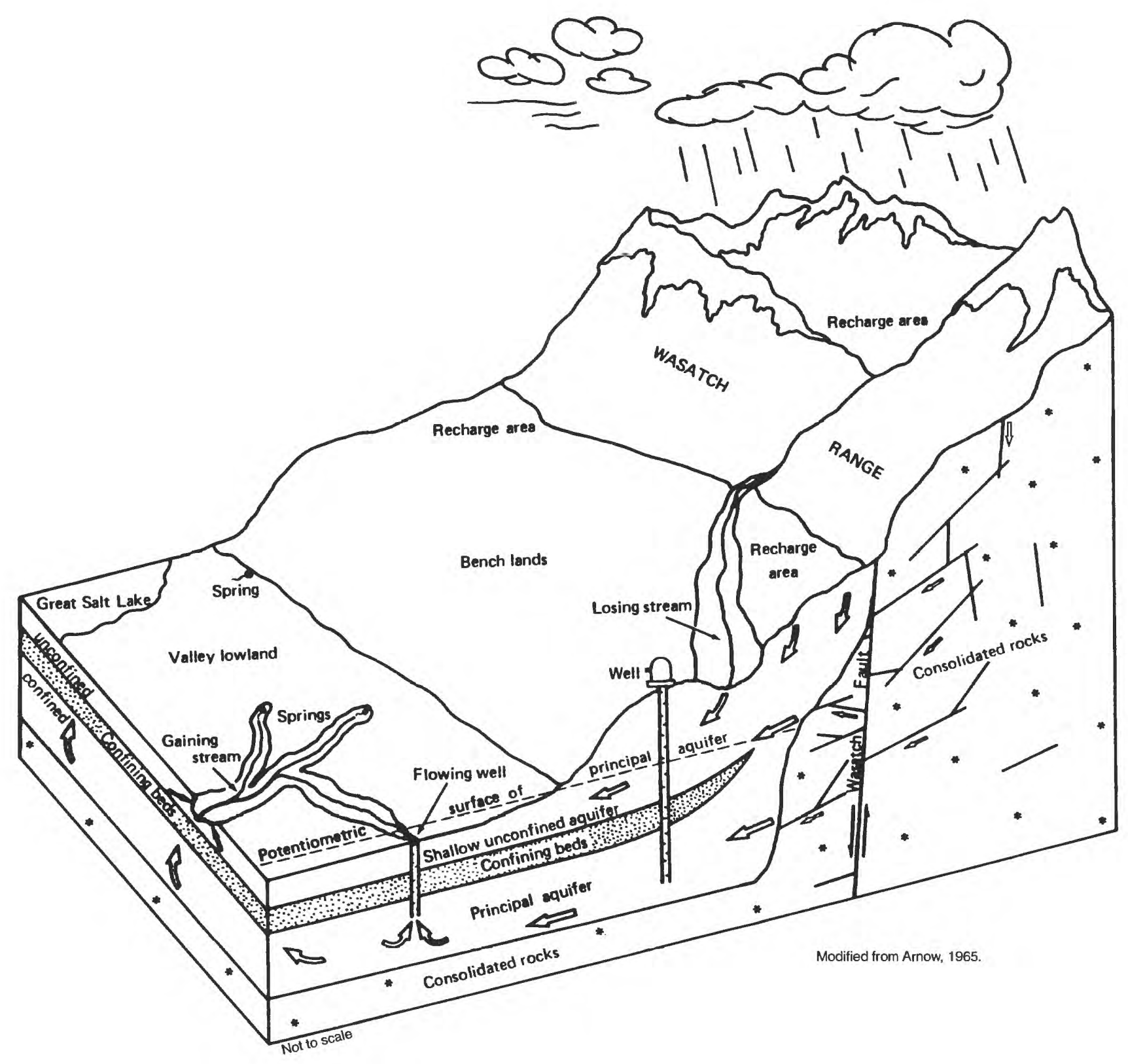

Figure 2. Generalized block diagram showing part of the hydrogeologic system in Salt Lake Valley. Arrows show general direction of ground-water flow. 
layers, and water from the principal aquifer moves upward through the confining layers into the shallow unconfined aquifer. The upward gradient generally prevents saline or contaminated water from the shallow unconfined aquifer from moving downward into the principal aquifer.

The principal aquifer in Salt Lake Valley (fig. 2) is recharged by subsurface inflow from fractured consolidated rock, infiltration of water from streams and canals, infiltration of excess irrigation water, infiltration of precipitation on the basin-fill sediments along the valley margins, or downward leakage from the shallow unconfined aquifer. Recharge from fractured consolidated rock occurs when rainfall, snowmelt, or runoff in the mountain areas moves into and along faults, joints, or solution cavities in the rock and discharges into unconsolidated basin-fill deposits at the edge of the valley. Water in the mountains that does not move down into faults, joints, or solution cavities in the consolidated rock, either evaporates, is transpired by plants or used by animals, or runs off in streams that eventually leave the mountains and flow across basin fill. As these streams flow into the valley, they cross the permeable sands and gravels that make up most of the recharge area along the mountain fronts. Some of this water infiltrates and moves down to the water table and into the principal aquifer, eventually becoming confined by relatively low-permeability clay lenses. The shallow unconfined aquifer is recharged by infiltration from precipitation, irrigation, and other surface sources, and by upward leakage from the principal aquifer.
Ground water naturally discharges from the principal aquifer in Salt Lake Valley by upward leakage to the shallow unconfined aquifer where it then discharges to springs, seeps, and streams, or is consumed by evapotranspiration in areas where the water table is shallow enough to support phreatophytes. Some ground water discharges to Great Salt Lake and large quantities of ground water are discharged through wells completed in the principal aquifer. Where the potentiometric surface is above land surface, wells completed in the principal aquifer will flow. Ground water must be pumpec' from wells in areas where the potentiometric surface is below land surface.

Water in the principal aquifer locally is saline and has been contaminated in the southwestern part of the valley by seepage of waste water and leachate from mining activities; the leachate contains large amounts of dissolved sulfate as well as dissolved copper, iron, lead and zinc (Waddell, Seiler, and Solomon, 1987, p. 16-21). Water in the shallow unconfined aquifer generally has higher concentrations of dissolved solids because the shallow aquifer includes sediments which contain salts left by the evaporation of Lake Bonneville of Pleistocene age and because salts have been concentrated in shallow ground water by evapotranspiration. Water in the shallow unconfined aquifer also has been contaminated by urban activities and sespage from landfills and mine and mill tailings areas, which result in local additions of organic chemicals, iron, and trace metals such as cadmium, arsenic, and manganese (Seiler and Waddell, 1984, p. 10-11). 


\section{SELECTED FACTORS AFFECTING \\ POTENTIAL FOR CONTAMINATION \\ OF THE PRINCIPAL AQUIFER}

Selected factors affecting the potential for contamination of ground water in the principal aquifer that were examined during this study fall into two general categories. First, some factors are related to movement of contaminants from the land surface to the principal aquifer (largely the process of recharge) and movement of contaminants after they reached the principal aquifer. Second, some factors are related to the potential effects of contaminants on the quality of ground water in the valley and in existing public-supply wells and springs. The potential origin of contaminants also is discussed.

\section{Potential Movement of Contaminants to and Within the Principal Aquifer}

\section{Recharge Areas}

The area where potential contaminants generally can move directly from the land surface to the principal aquifer is the aquifer's primary or direct recharge area, shown on plate 1 . In this area, basin-fill deposits are predominately coarse grained; fine-grained beds which could impede downward movement of water to the principal aquifer are largely absent. This area was defined by Hely and others (1971, fig. 58) as the area where ground water is unconfined, and was later modified slightly by Waddell and others (1987, fig. 4) during the process of construction and calibration of their digital model. The recharge area includes some locations where the principal aquifer, although unconfined, is overlain by a perched aquifer (Hely and others, 1971, fig. 58). Water in this aquifer probably is perched by fine-grained beds of low permeability, which impede direct movement of water to the principal aquifer in these locations. The secondary recharge are $\varepsilon$, generally located just downgradient from the primary area, is where the principal aquifer is confined by fine-grained beds but where the hydraulic gradient is downward from the overlying shallow unconfined aquifer to the principal aquifer. A discussion of the various sources of recharge to the principal aquifer is given in the following two sections of the report. 


\section{Subsurface Inflow from Fractured Consolidated Rock}

About 45 percent of the total recharge to the principal aquifer is by subsurface inflow from fractured consolidated rock (Waddell and others, 1987, p. 9). This recharge occurs in a narrow zone immediately adjacent to the mountain fronts (fig. 3 ), and the estimated amount probably includes some recharge from ephemeral and intermittent streams. Annual totals for recharge from subsurface inflow to the principal aquifer for 1969-82 ranged from 85,000 to 205,000 acre-feet per year and averaged 157,000 acre-feet per year (Waddell and others, 1987, p. 11). Water for recharge from fractured consolidated rock is supplied primarily by snowmelt runoff in the spring with minor contributions from spring and summer thunderstorms. This water enters the ground-water system by percolation through a relatively thin sediment cover over fractured rock. Ground water moves through these fractures and eventually into the permeable unconsolidated sediments of the basin fill adjacent to the mountains. The exact area in the mountains that contributes water for subsurface inflow to the basin-fill deposits is not known. Most of the mountain areas in the Wasatch Range, east of the valley, are U.S. Forest Service land, so land development that creates sources of contamination is restricted.

The mountains to the east and west of Salt Lake Valley are critical source areas for water for recharge, and the adjacent basin-fill areas are critical recharge areas for the principal aquifer. Transmissivity values are largest in basin-fill deposits close to the mountain fronts, and most of the recharge to the principal aquifer occurs in this zone. If contamination of surface water were to occur in the mountains due to a spill of hazardous material or as the result of increased development, or if contamination of ground water were to occur near the contact between the fractured rocks and basin-fill deposits, contamination of the principal aquifer would be inevitable.

The locations where water moves from the fractured consolidated rock of the mountains into the unconsolidated basin fill are not well defined. They likely are related to the quantity and areal distribution of precipitation in the mountains as well as the orientaticn, lateral and vertical extent, density, and size of fractures in the rock. Uncertainties in these factors and their distribution result in uncertainties in the locations of subsurface inflow. Because these factors are not well known, and in some parts of the valley are poorly known, the locations of subsurface inflc' $v$ are approximate. The digital model constructed by Waddell and others (1987) simulated inflow from consolidated rock in the areas shown in figure 3 . The rates of inflow ara governed by the hydraulic gradients and transmissivities assumed for the model, but presumably they also indicate areas where actual inflows are largest.

Estimates of the average volume of water entering the sediments directly from fractured consolidated rock (and infiltration of water in ephemeral and intermittent streams) range from 135,000 acre-feet per year (Hely ard others, 1971 , p. 119) to 157,000 acre-feet per year (Waddell and others, 1987, p. 11). Hely and others $(1971$, p. 121) estimated that the net mean subsurface flow from fractured consolidated rock was about 106,000 acre-feet per year from the Wasatch Range and about 29,000 acre-feet per year from the Oquirrh Mountains. Waddell and others (1987) $c^{\prime \prime} d$ not distinguish between recharge quantities from the Wasatch Range and Oquirrh Mountains. 


\section{EXPLANATION}

Flow rates, in cubic feet per second

Greater than 0 to 0.1

Greater than 0.1 to 0.2

Greater than 0.2 to 0.5

Greater than 0.5 to 0.8

Greater than 0.8 to 1.1

Greater than 1.1

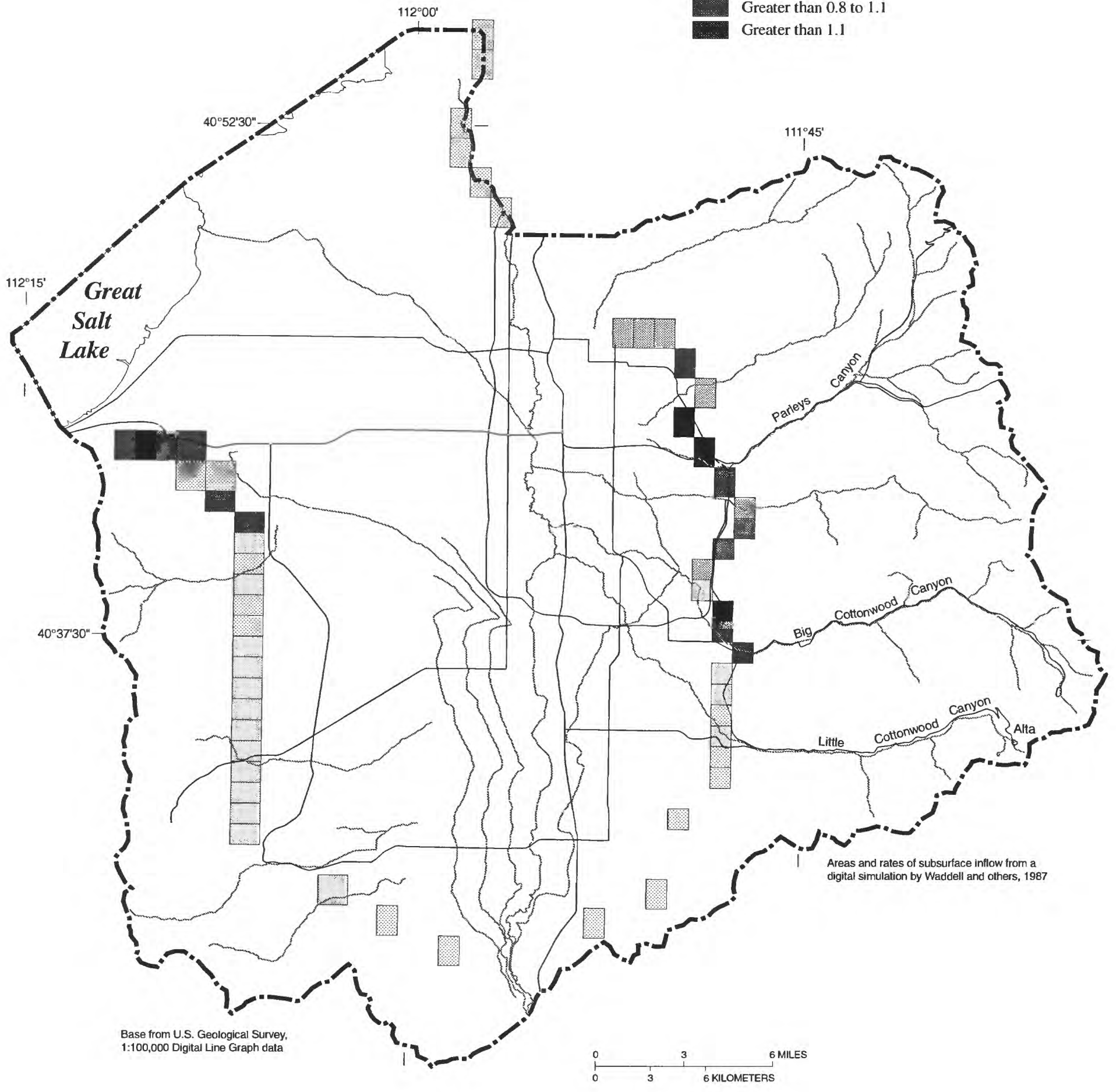

Figure 3. Areas of subsurface inflow to the principal aquifer from fractured consolidated rock. 
In addition to subsurface inflow from consolidated rocks, recharge directly to the basinfill deposits in Salt Lake Valley occurs by infiltration of surface water as it leaves the mountains and crosses these deposits. Direct recharge to the principal aquifer can occur in areas where the confining layer is absent. Streams, unlined canals and ditches, irrigation, and precipitation are all contributors to recharge. Recharge to the principal aquifer from surface water in Salt Lake Valley occurs primarily from reaches of streams and unlined canals and from direct infiltration of precipitation along the mountain fronts (fig. 4). Figure 4 shows the approximate areas where the confining beds are absent-the recharge areas-and where water can thus move directly from the land surface to the water table and to the principal aquifer.

Streams, canals, irrigation, and precipitation also supply water for recharge to the shallow unconfined aquifer throughout most of the valley. In areas where the potentiometric surface of the shallow unconfined aquifer is higher than the potentiometric surface of the principal aquifer, water potentially can move through the confining beds into the principal aquifer.

Many factors influence the rate of infiltration of water in a particular area. These factors include the lithology, hydraulic conductivity, and slope of the surface deposits, and the elevation of the local water table relative to the land surface. Channels formed naturally or by man may expose subsurface sediments to water in streams, canals, and ditches. Many of these subsurface sediments may be more permeable than surface soils and sediments, allowing a greater rate cf infiltration. The largest rates of infiltration occur along the mountain fronts to the east and west of the valley (Hely and others, 1971, p. 114).

Streams, canals, irrigation, and precipitation recharge both the principal and the shallow unconfined aquifers. Waddell and others $(1987$, table 1) estimated that abcut 20 percent, or 72,000 acre-feet per year, of the total recharge to both the principal and shallow unconfined aquifers in Salt Lake Valley comes from seepage from canals and irrigated fields with another 20 percent from precipitation. Hely and others (1971, p. 123) estimated seepage from stream channels on the east side of the valley to be about 17,700 acre-feet per year, and from the west side of the valley about 1,000 acre-feet per year. Hely and others $(1971$, p. 119) estimated the contribution to both aquifers from direct irfiltration of precipitation to be about 60,000 acrefeet per year. The total volume of recrarge from streams, canals, irrigation, lawns and gardens, and precipitation was estimated by Hely and others (1971, p. 119) at about 226,000 acre-feet per year; whereas $W \varepsilon$ ddell and others (1987, p. 9), estimated this vc'ume to be about 187,000 acre-feet per year. The remainder of recharge to the ground-ivater system in Salt Lake Valley comes from underflow from Utah Valley, reinjection from air conditioning, and underflow in channel fill. 


\section{EXPLANATION}

Flow rates, in cubic feet per second

Greater than 0 to 0.1

Greater than 0.1 to 0.2

Greater than 0.2 to 0.6

Greater than 0.6 to 1.2

Greater than 1.2 to 5

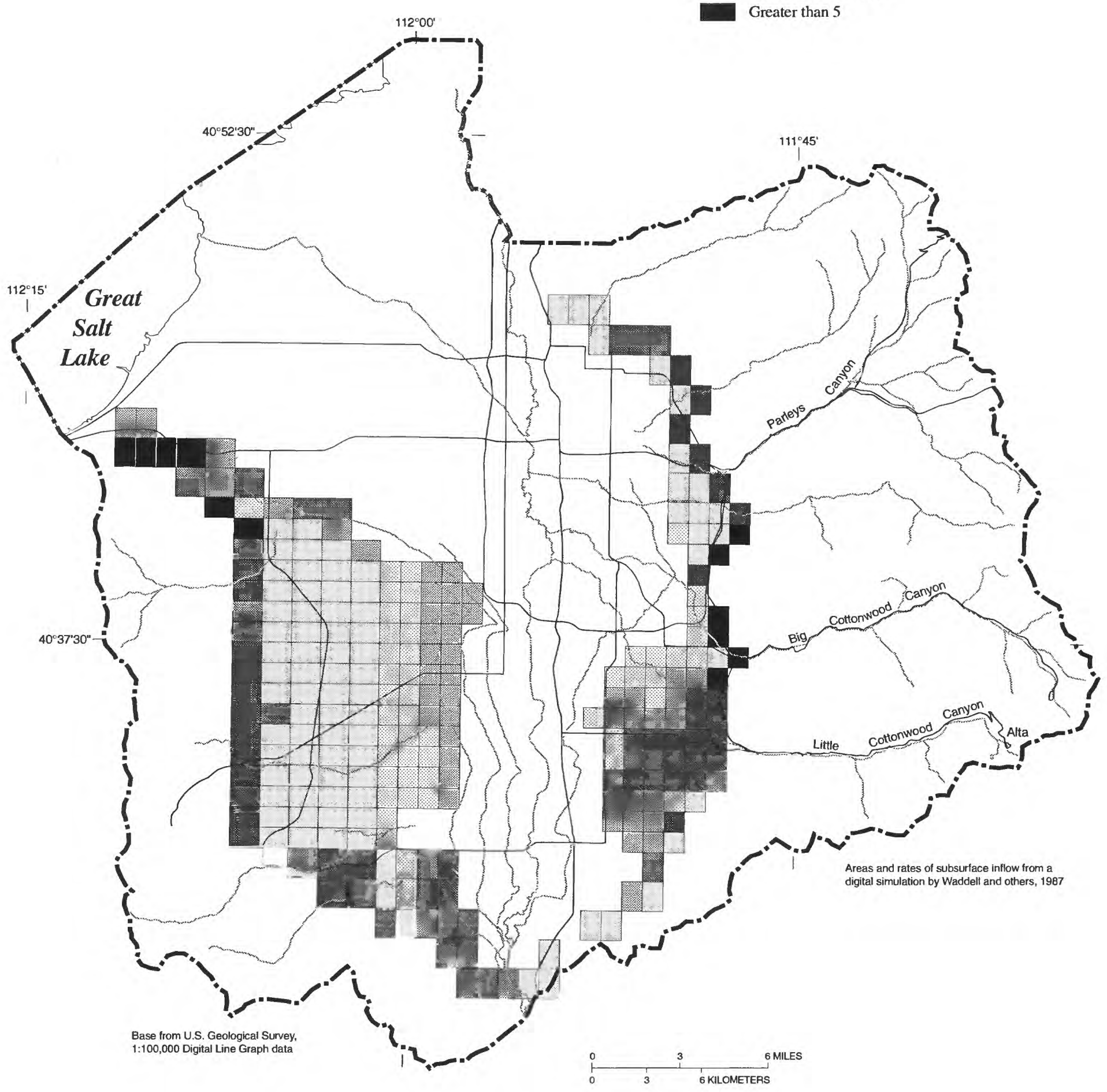

Figure 4. Areas of recharge to the principal aquifer from streams, canals, irrigation, and precipitation. 


\section{Direction of Ground-Water Flow}

The direction of ground-water flow is influenced strongly by whether the water is located in the unsaturated or saturated zone. In the unsaturated zone, gravity, degree of saturation, and the lithology of the material influence the movement of water. In the saturated zone, the local hydraulic gradient, hydraulic conductivity, and gravity become the principal factors controlling movement.

Ground water in the principal aquifer moves in the direction of the slope of the potentiometric surface. Water-level contours for 1983 for the principal aquifer (fig. 5) show the potentiometric surface decreasing in altitude toward the Jordan River and subsequently, toward Great Salt Lake. The movement of ground water in the principal aquifer, therefore, is toward the Jordan River and eventually toward Great Salt Lake. Irregularities in the slope of the potentiometric surface are caused by local differences in additions or withdrawals of water and by differences in the thickness or hydraulic conductivity of aquifers.

Aquifer contaminants generally move in the direction of ground-water flow. Contaminants entering the principal aquifer near the mountain fronts will move through the aquifer in the direction of decreasing potentiometric surface altitude toward Great Salt Lake (fig.
5). The rate of ground-water movement varies within Salt Lake Valley and is extremely slow when compared to the movemen+ of surface water.

Higher hydraulic head in the principal aquifer compared to the shallow unconfined aquifer at a given location indicates upward movement from the principal to the shallow unconfined aquifer. Assuming that the confining beds are relatively uniform, this component of ground-water movement is greatest where the difference botween the hydraulic head of the principal aquifer and the hydraulic head of the shallow unconfined aquifer is greatest. If the hydraulic head of the principal aquifer were to drop below the hydraulic head of the shallow unccnfined aquifer, a downward component of movement would result. Figure 5 shows areas where vertical movement of ground water is upward from the principal aquifer to the shallow unconfined aquifer or downward friom the shallow unconfined aquifer to the principal aquifer.

The general direction of horizontal groundwater movement in the shallow unconfined aquifer is similar to movement in the principal aquifer. This movement is towarc the Jordan River, except in the extreme nortrivest part of the valley, where it moves towarid Great Salt Lake. 


\section{EXPLANATION}

Direction of ground-water flow in the principal aquife Upward ground-water flow from principal aquifer to shallow unconfined aquifer

Downward ground-water flow from shallow unconfined aquifer to principal aquifer

Direction of horizontal ground-water flow

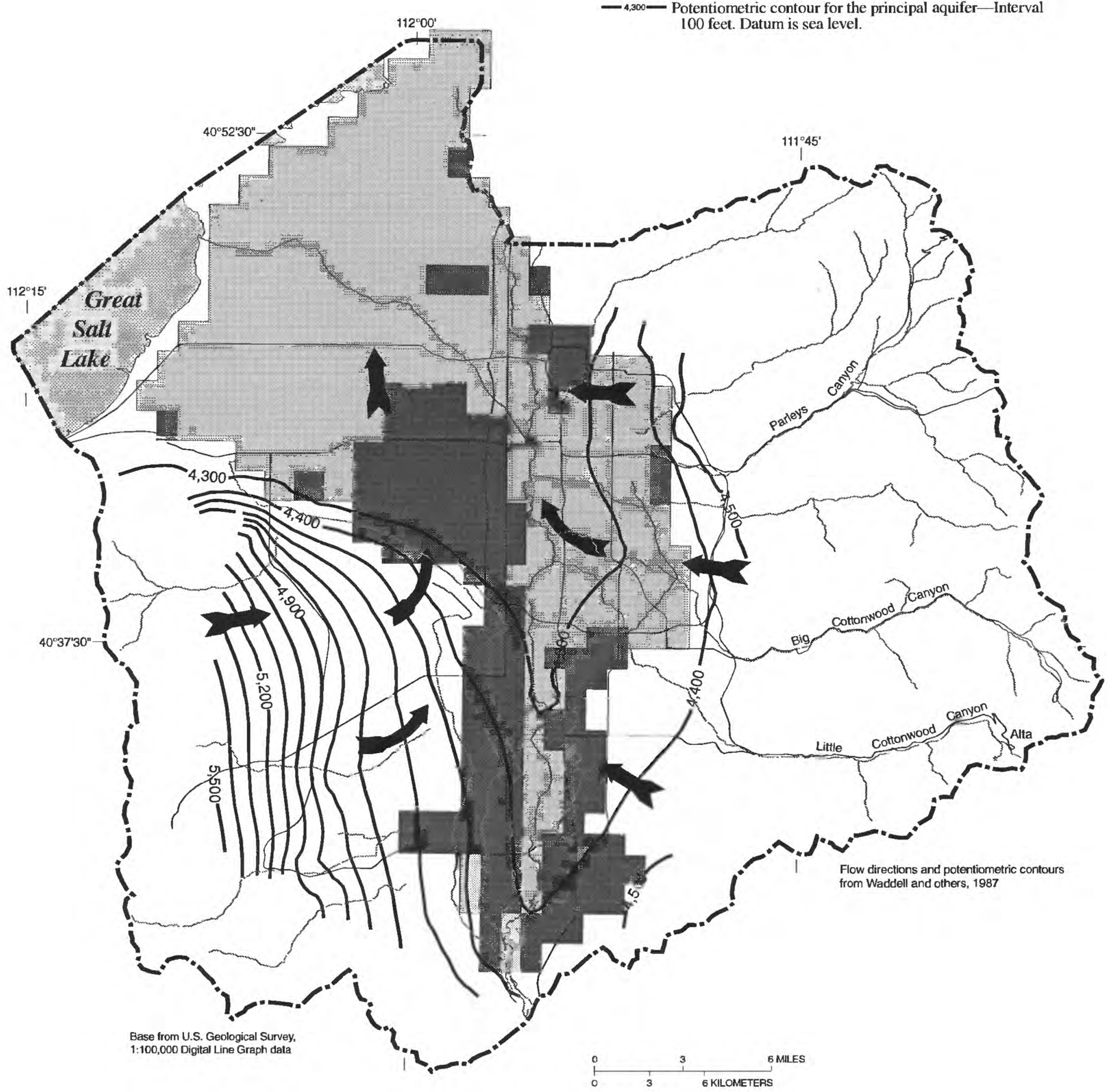

Figure 5. General direction of horizontal and vertical ground-water flow in Salt Lake Valley. 


\section{Transmissivity}

Areas in Salt Lake Valley where values of transmissivity (defined as the hydraulic conductivity of the aquifer multiplied by the saturated thickness of the aquifer) are large, tend to be areas where ground-water velocities also are large. If contaminants enter ground water in areas where velocities are large, they will migrate relatively rapidly away from the point of contamination, and the contamination will be more difficult to control. Transmissivity values used in the groundwater model of Salt Lake Valley (Waddell and others, 1987) were estimated using data obtained from aquifer tests and derived from calibration of the model. They ranged from less than 500 to more than 50,000 feet squared per day (fig. 6). These values were similar to those used by Hely and others (1971, p. 113) in constructing an electric-analog model of Salt Lake Valley, with the exception of the southern part of the valley where modifications were made in transmissivity values during the digital model calibration (Waddell. and others, 1987).

Transmissivity values are largest along the eastern edge of Salt Lake Valley with local areas of large values near the mouths of Big and Little Cottonwood Canyons and Par- leys Canyon (fig. 6). Transmissivity values in these locations are greater than 50,000 feet squared per day. Transmissivity values along the west side of the valley are less than 1,000 feet squared per day (Hely and c thers, 1971, fig. 59).

Transmissivity can be related to the apparent velocity of ground-water flow. Apparent velocity can be defined as the product of hydraulic conductivity and hydraulic gradient divided by aquifer effective porosity. If aquifer thickness, hydraulic gradient, and porosity are constant, transmissivity is directly proportional to apparent velocity. In Salt Lake Valley, aquifer thickness tends to be less at the edges of the valley (Hely and others, 1971, fig. 64), and the variation in porosity over the valley is not known, although it may not vary in any easily predictable pattern. Because the hydraulic gradient tends to be largest along the eastern edge of the valley (Holy and others, 1971, pl. 1), where transmiscivity values are largest (fig. 6), velocities probably are largest in areas of large transmissivity. A contaminant reaching the water table in an area of large transmissivity co.sld quickly move from the recharge area downgradient to where many public-supply wells are located. 


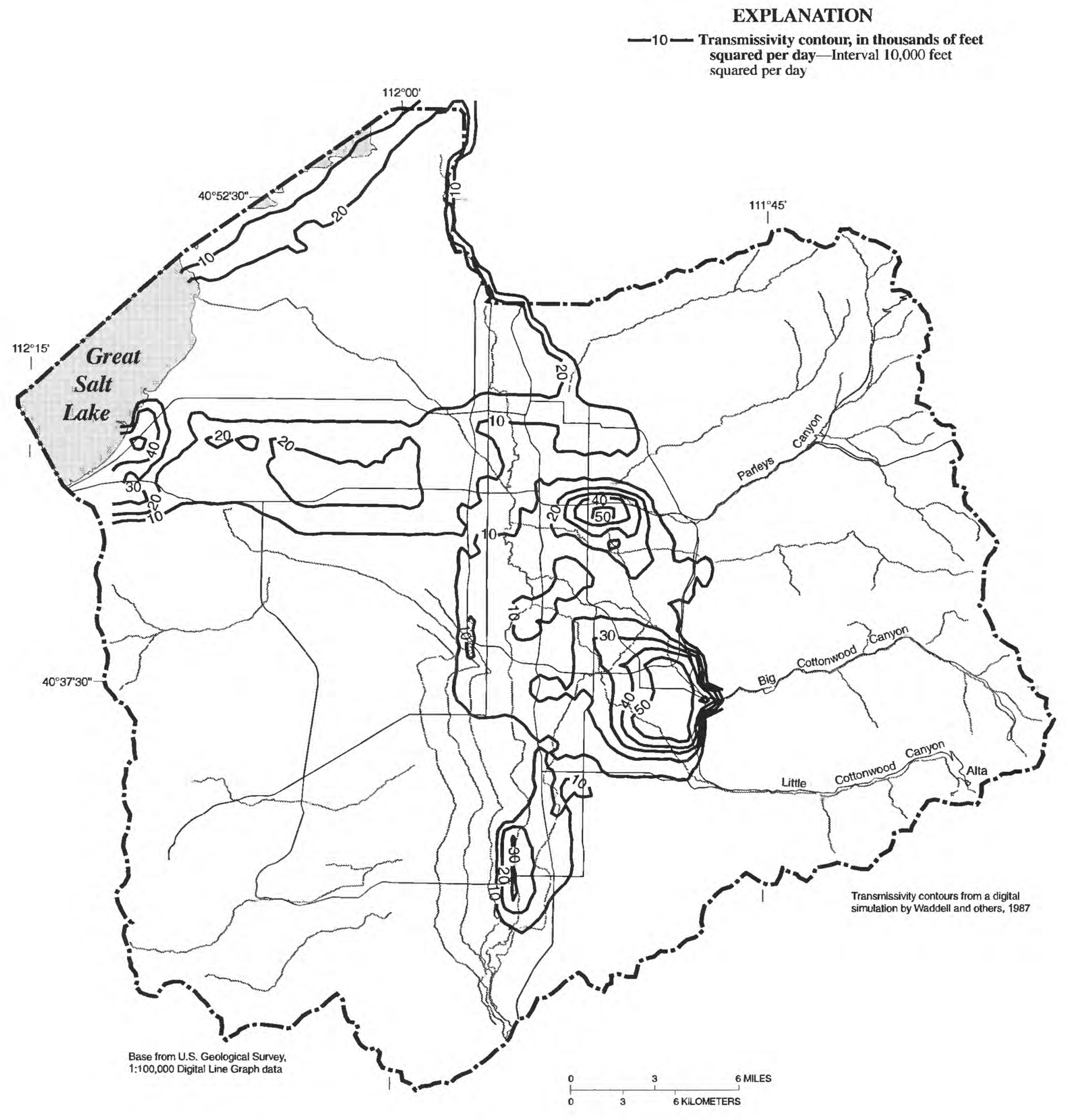

Figure 6. Transmissivity contours used in a digital model of the principal aquifer. 


\section{Potential Effects and Origin of Contaminants}

\section{Distribution of Dissolved Solids in Water of the Principal Aquifer}

The natural chemical quality of ground water depends on the chemical quality of the recharge water, the chemical and physical properties of the rocks or sediments through which it passes, the length of time the ground water is in contact with the rocks or sediments, chemical reactions occurring in the ground water, and biological processes. It is important to know where the quality of water in the principal aquifer is best and where it is withdrawn for public supply. In these areas, the resource probably is the most valuable, and contamination would have the most serious consequences.

Dissolved-solids concentrations in water in the principal aquifer in Salt Lake Valley generally meet the standards for a public drinking-water supply. Dissolved-solids concentrations range from about 100 milligrams per liter $(\mathrm{mg} / \mathrm{L})$ near the Wasatch Range to about $10,000 \mathrm{mg} / \mathrm{L}$ near Great Salt Lake (fig. 7). Local areas of ground water contain dissolved-solids concentrations of about 74,000 $\mathrm{mg} / \mathrm{L}$ due to ground-water contamination resulting from mine-tailings leaching operations (Waddell, Seiler, and Solomon, 1987, p. 20).

Dissolved-solids concentrations in the principal aquifer vary laterally (fig. 7 ) and with depth. In general, water in the principal aquifer with the smallest dissolved-solids concentrations occurs closest to the main areas of recharge along the Wasatch Range, while the largest dissolved-solids concentrations occur in ground water in the areas of discharge nearest Great Salt Lake. Hely and others (1971, p. 159) explain these areal differences as resulting from a progressively greater opportunity for solution of minerals as the water moves through the aquifer. Because the majority of the water recharging the principal aquifer in Salt Lake Valley comes from the Wasatch Range, the quality of ground water near these mountains reflects the quality of recharge. Dissolved-solids concentrations are smallest in the area where recharge is derived from $B: x$ and Little Cottonwood Canyons (fig. 7).

The suitability of ground water for public supply is primarily based on the total concentration of the major dissolved constituents in the ground water (U.S. Environmental Protection Agency, 1987). The U.S. Environmental Protection Agency (EPA) has established a secondary standard of $500 \mathrm{mg} / \mathrm{L}$ for dissolved solids in drinking water (U.S. Environmental Protection Agency, 1987). This secondary standard was established to provide guidance in evaluating the aesthetic qualities of drinking water (U.S. Environmental Protection Agency, 1987). The primary maximum contaminant level for dissolved solids in the S'ate of Utah is $2,000 \mathrm{mg} / \mathrm{L}$ for community wat 2 r systems. This primary level is set by the Utah Department of Health and is for the protection of public health.

The principal aquifer has been contaminated by leachate and waste water from mining operations and by leachate from mill tailings in local areas of Salt Lake Valley. Ground water between the mouth of Bingham Canyon (in the Oquirrh Mountains) and the Jordan River, (about 10 miles to the east of the mountains) has increased levels of dissolved solids associated with seefage related to mining activities, leaching of $m^{\text {ine tailings, }}$ two evaporation ponds, and a large holding reservoir. Much of this leachate is acidic and has dissolved-solids and sulfate concentrations greater than $10,000 \mathrm{mg} / \mathrm{L}$ (Waddell, Seiler, and Solomon, 1987, p. 1ᄃ.20). Many domestic and irrigation wells in the area now yield water with concentrations $\mathrm{cf}$ dissolved solids that exceed 2,000 mg/L (Waddell, Seiler, and Solomon, 1987, p. 24). Water in the upper part of the principal aquifer probably has been contaminated by leachate containing large concentrations $c f$ dissolved solids, chloride, sulfate, and iron from uranium-ore tailings in the north-central part of the valley (Waddell, Seiler, anc' Solomon, 1987, p. 31-35). 


\section{EXPLANATION}

-500- Dissolved-solids contour, in milligrams per liter-Interval variable

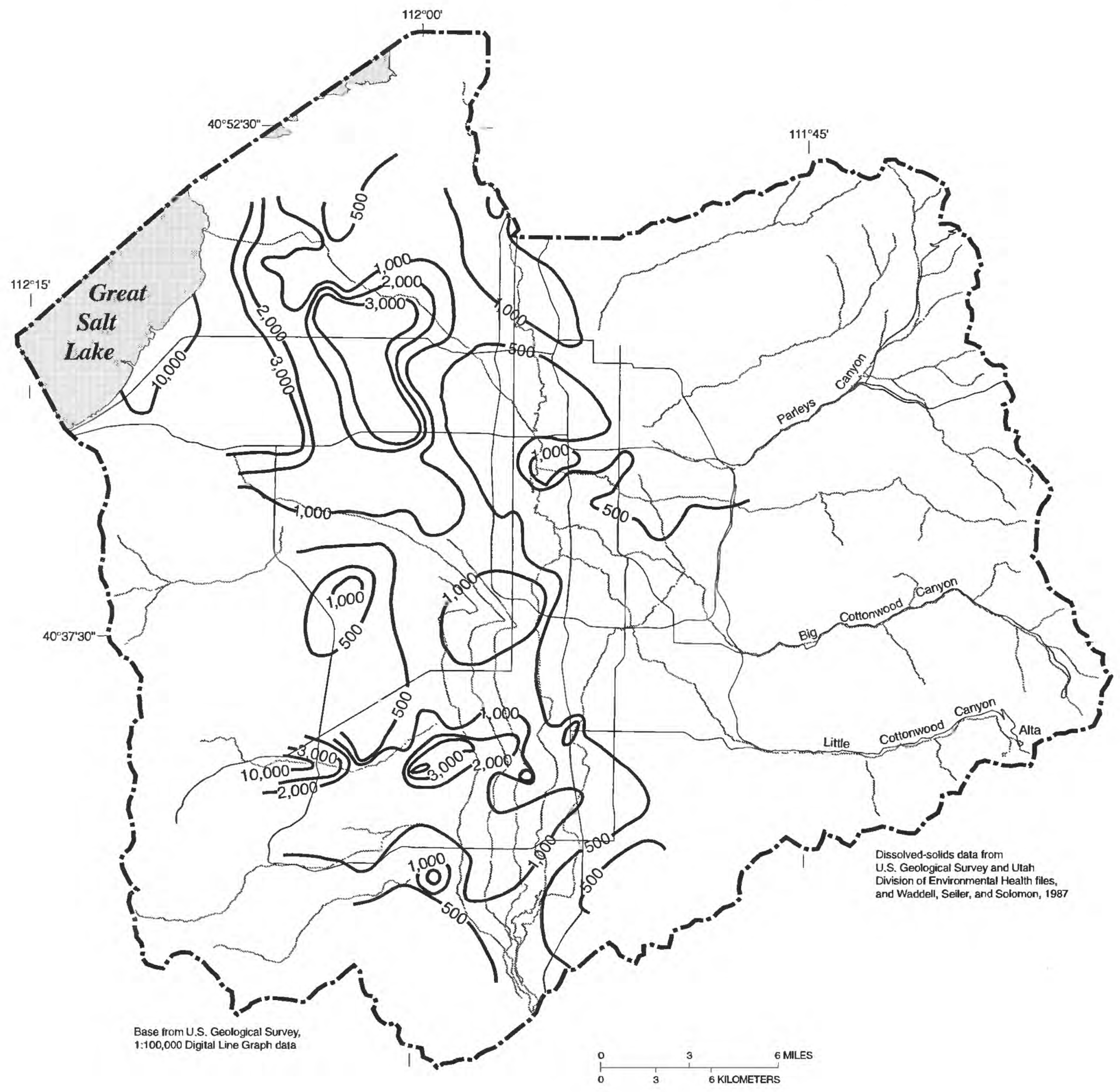

Figure 7. Distribution of dissolved solids in ground water of the principal aquifer. 
Distribution of Dissolved Solids and Presence of Contaminants in Water of the Shallow Unconfined Aquifer

The quality of water in the shallow unconfined aquifer is important in an assessment of the potential for contamination of the principal aquifer because if the vertical hydraulic gradient is downward, water can move from the shallow unconfined aquifer to the principal aquifer. The shallow unconfined aquifer is recharged by infiltration from surface sources such as precipitation, irrigation, seepage from streams and canals, and upward leakage from the principal aquifer. Generally, water in the shallow unconfined aquifer contains a greater concentration of dissolved solids than water in the principal aquifer (fig. 8). Seiler and Waddell $(1984$, p. 9) reported that the range in dissolved-solids concentrations for water in the shallow unconfined aquifer was less than $1,000 \mathrm{mg} / \mathrm{L}$ to $29,000 \mathrm{mg} / \mathrm{L}$.

The smallest concentrations of dissolved solids in the shallow unconfined aquifer are on the east side of Salt Lake Valley and the greatest concentrations are along the northwest edge of the valley, near Great Salt Lake (fig. 8). Possible sources of dissolved solids in ground water in the shallow unconfined aquifer may be a combination of: (1) the solution of minerals as water from the principal aquifer moves upward through the confining beds into the shallow unconfined aquifer; (2) evapotranspiration concentrating dissolved solids in areas where the water level in the shallow unconfined aquifer is or has been close to the land surface; (3) infiltration of irri- gation water; (4) contamination from salts applied to de-ice roads; and (5) the solution of minerals within the shallow unconfined aquifer (Hely and others, 1971, p. 159).

The shallow unconfined aquifer in much of Salt Lake Valley is contaminated (Waddell, Seiler, and Solomon, 1987, p. 4). Contamination probably is by recharge water with large dissolved-solids concentrations or by waste fluids with large dissolved-solids concentrations percolating directly into the aquifer itself. Solid-waste dumps, landfills, road salt, and tailings ponds carry an inherent potential for contamination of the ground water. Water moving through or over these sources of contamination dissolves constituents from the waste and can carry them into the groundwater system. Urban activities such as the application of insecticides and herbicides to lawns, oil and gas spills, and runoff from streets and other paved or urban areas also contribute to contamination of the shallow unconfined aquifer. Industrial effluents, sewage, and hazardous wastes all can contribute to the contamination of ground water. Organic chemicals and large concentrations of trace elements have been detected in water from several monitoring wells completed in the shallow unconfined aquifer in Salt Lake Valley, with the greatest concentrations of organic chemicals and trace elements found adjacent to landfills or tailings areas (Seiler and Waddell, 1984, p. 1). 


\section{EXPLANATION}

$-1,000$ - Dissolved-solids contour, in milligrams per liter-Interval variable

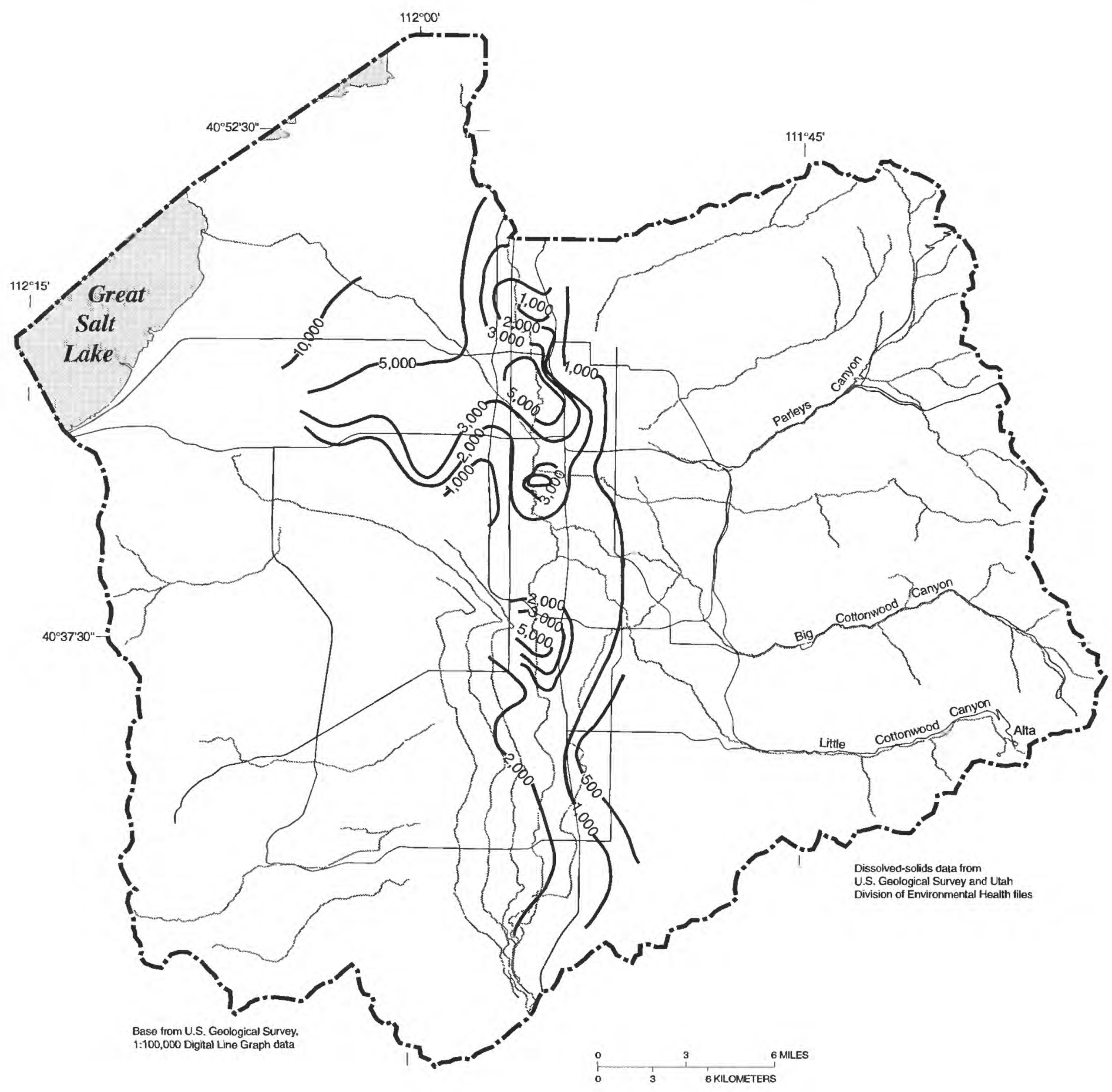

Figure 8. Distribution of dissolved solids in ground water of the shallow unconfined aquifer. 
The digital-computer model (Waddell and others, 1987) can be used to predict the effects on hydraulic gradient and vertical flow of an increase in pumping from wells, as shown by the simulation results portrayed in figures 9 through 11 . These simulations are useful in identifying areas that are susceptible to contamination due to reversals of the hydraulic gradient and direction of vertical flow. Large withdrawals from a well or a group of wells can cause a local reversal of the vertical hydraulic gradient and cause contaminated water from the shallow unconfined aquifer to move downward and eventually enter the underlying principal aquifer if the reversal in gradient persists for a sufficient length of time.

A series of hypothetical pumping scenarios (figs. 9-11) was prepared for this report beginning with the calibrated water levels from the digital simulation. The initial simulation was made with the digital model by maintaining the 1982 rate of withdrawals from wells $(115,000$ acre-feet) through the year 2000. Wells with discharge equal to or greater than 0.3 cubic foot per second were then assigned increased discharge to simulate the effect of increasing pumping rates. The pumpage rate was increased in steps of 2,3 , and 4 times the original value. Areas where the simulated hydraulic gradient was reversed as pumping increased are shown in figures 9 through 11. Reversals occurred in the simulation when the head in the principal aquifer became lower than the head in the shallow unconfined aquifer. This situation would cause water in the shallow unconfined aquifer to move down toward, and ultimately into, the principal aquifer. If saline or contaminated water was present in the shallowunconfined aquifer in these areas, contamination or deterioration in the quality of water in the principal aquifer would result if the hydraulic gradient was reversed for a long enough period to allow exchange of water between aquifers. Simulated reversals of the hydraulic gradient occurred primarily in the north and central parts of the valley (figs. 9-11). Comparison of figures 11 and 8 shows that the simulated reversal of the ground-water-flow direction occurred where the shallow unconfined aquifer contains relatively large concentrations of dissolved solids. 
EXPLANATION

Pumpage multiplier at which reversal occurred 2 times original rate

- Wells with original pumping rates greater than 0.3 cubic foot per second

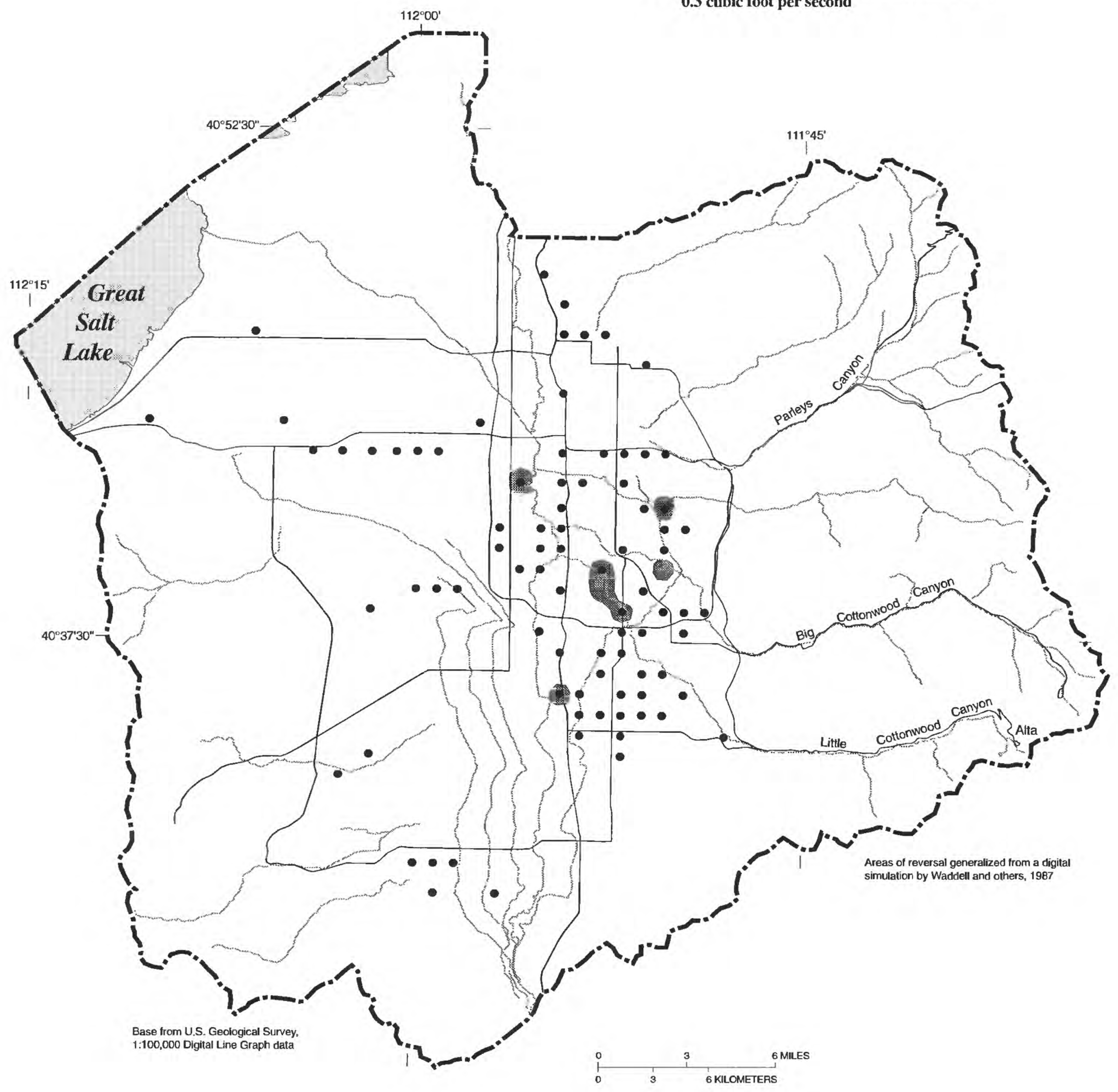

Figure 9. Areas where vertical hydraulic gradient could be reversed with a two-fold increase in pumping. 


\section{EXPLANATION}

Pumpage multiplier at which reversal occurred 3 times original rate

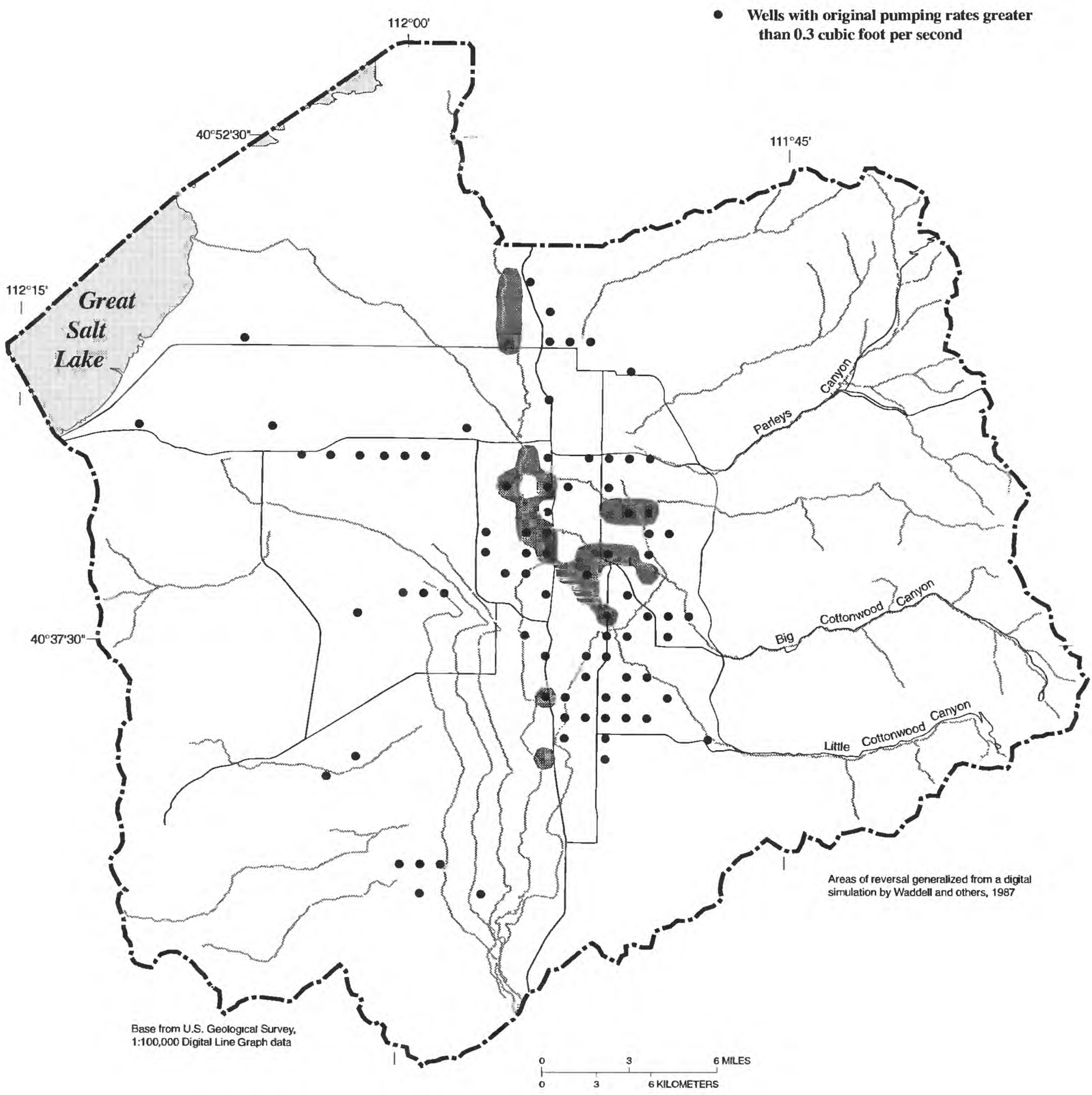

Figure 10. Areas where vertical hydraulic gradient could be reversed with a three-fold increase in pumping. 


\section{EXPLANATION}

Pumpage multiplier at which reversal occurred 4 times original rate

- Wells with original pumping rates greater

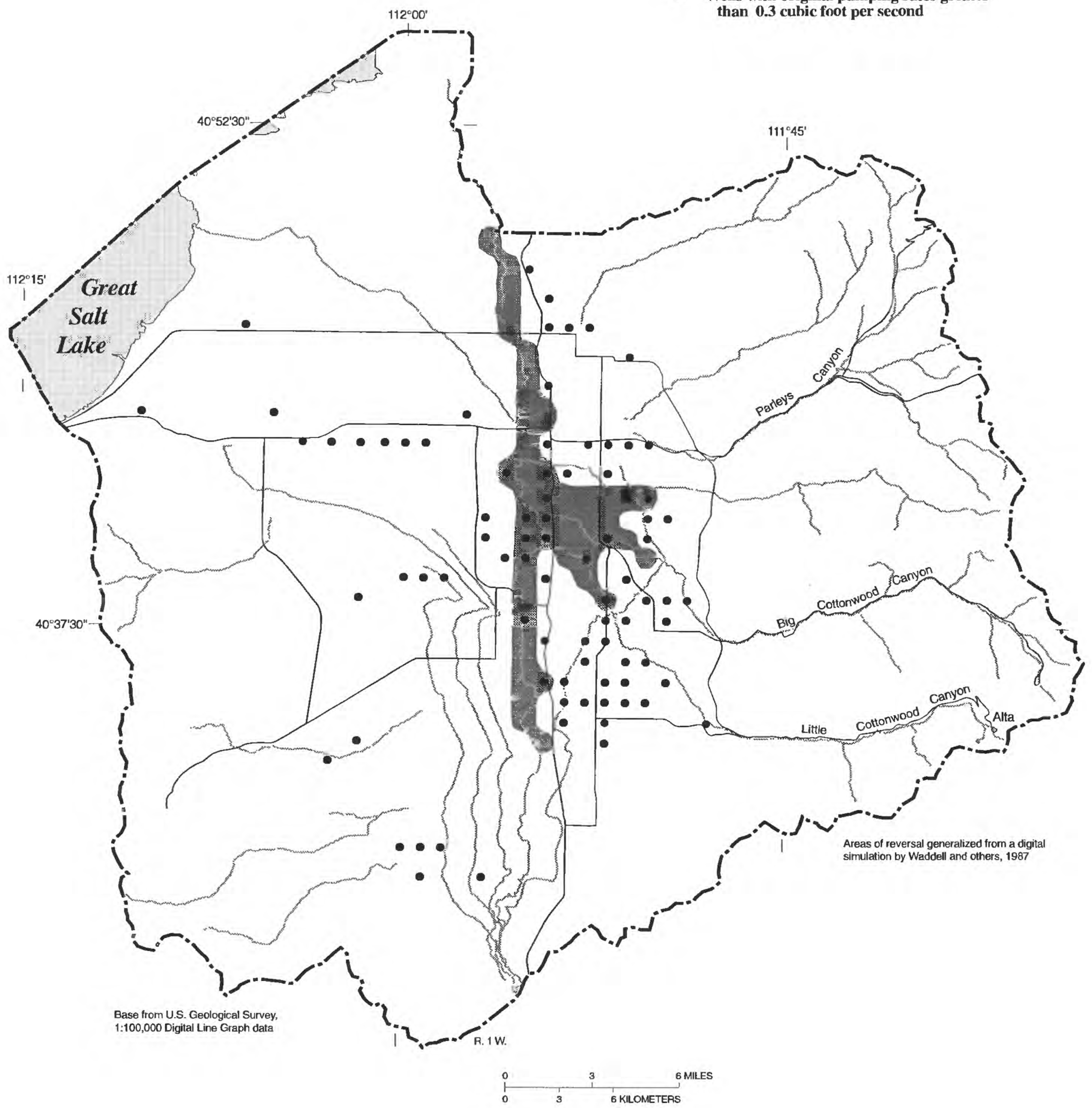

Figure 11. Areas where vertical hydraulic gradient could be reversed with a four-fold increase in pumping. 
Locations of Public-Supply Wells and Springs, Urbanized Areas, and Hazardous-Waste Sites

The locations of public-supply wells and springs, urbanized areas, and hazardouswaste sites can be important factors in the origin and ultimate effects of contaminants on the quality of ground water used for public supply in Salt Lake Valley. The potential for groundwater contamination accompanies the spread of urban development into recharge areas. Activities of industries that generate hazardous waste or chemicals, withdrawals of water that result in water-level declines in the vicinity of hazardous-waste sites, and withdrawals that result in the movement and redistribution of saline or contaminated water from the shallow unconfined aquifer all may contribute to the spread of saline water or contaminants in the ground-water system.

The growth of residential and commercial/ industrial areas in Salt Lake Valley (fig. 12) has changed land use in the recharge areas of the principal aquifer and created a potential contamination hazard for the groundwater system. Activities associated with urban expansion and industrialization that can contribute contaminants to the groundwater system include application of road salts, lawn and tree spraying for pest control, fertilizer application, disposal of waste fluids, oil and gas spills, runoff from streets and other paved or urban areas, and leaching of landfills, dumps, or hazardous-waste sites. These activities introduce contaminants into the environment that can infiltrate the land surface and migrate into the aquifer that is used for public supply.
Movement of contaminants into the principal aquifer can occur directly, and locally can occur rapidly in the unconfined part of the aquifer-the main recharge area. Urban growth in these areas of potential recharge to the unconfined part of the principal aquifer has increased the possibility of contamination. Urbanization also has occurred in areas underlain by the shallow unconfined aquifer.

Most of the public-supply wells and springs are located in the eastern half of Salt Lake Valley (fig. 12), and most are several miles from any known hazardous-waste site. However, more than 40 public-supply wells are located less than one mile from a hazardous-waste site (pl. 1). Some of these wells also are in areas where a doubling in the 1982 pumping rate could reverse the direction of ground-water flow (pl. 1). This reversal could induce downward movement of contaminants from the shallow unconfined aquifer toward the principal aquifer from which the public-supply wells withdraw water. More than half of the public-supply wells are located in the recharge area for the principal aquifer, and much of this land has been altered to support residential or commercial development (fig. 12). If fluids containing contaminants were to infiltrate in recharge areas or if contaminants were introduced into surface water above the recharge areas, contaminants could migrate directly into the principal aquifer. The time required to reach the publicsupply wells in the recharge area would be relatively short. 
EXPLANATION

Land-use classification

Commercial/Industrial

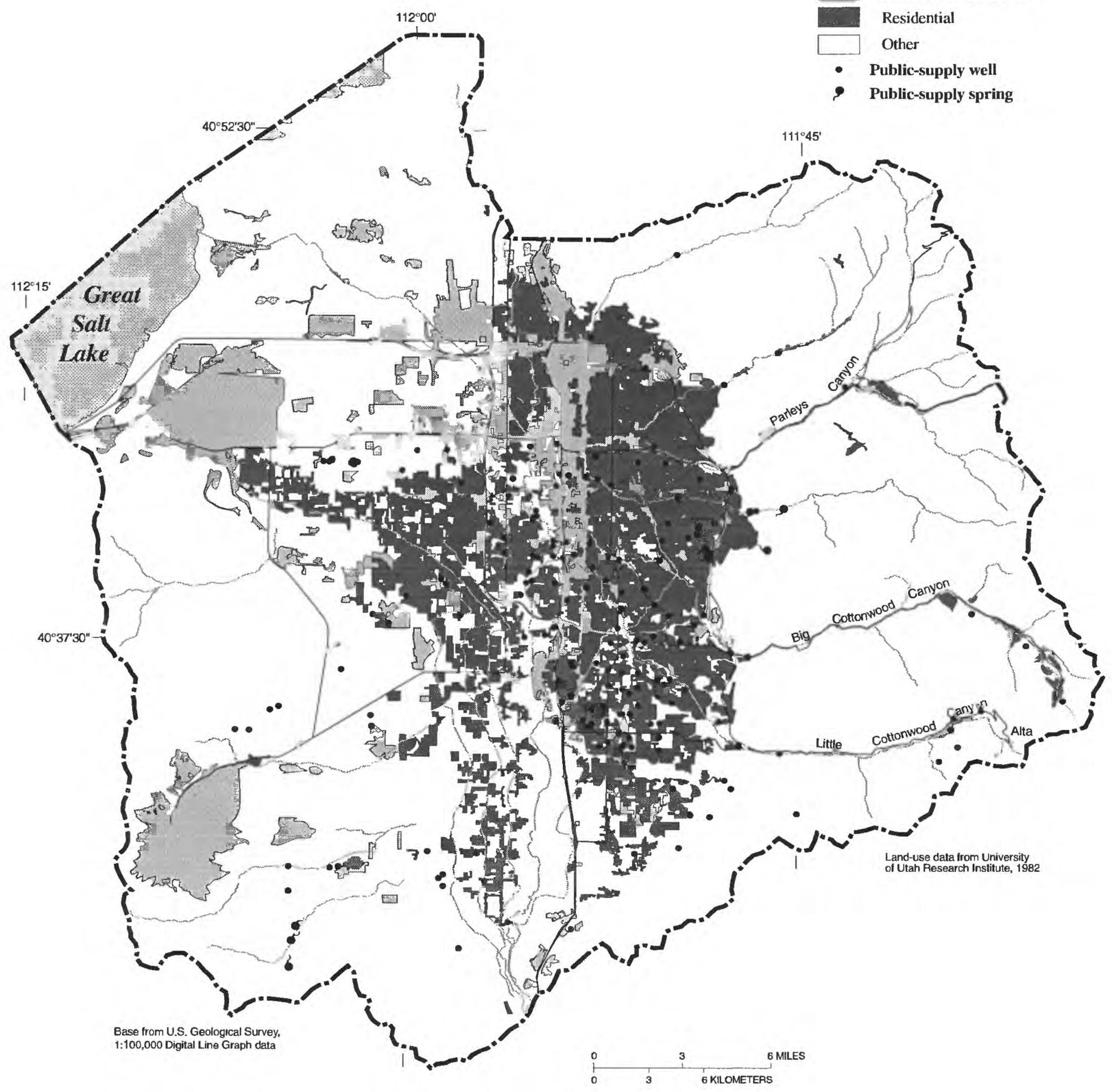

Figure 12. Public-supply wells and springs and extent of urbanization in Salt Lake Valley. 


\section{SUMMARY AND CONCLUSIONS}

Some of the factors related to the potential for contamination of the principal aquifer of the Salt Lake Valley were evaluated in two categories. The first category includes factors related to potential movement of contaminants to and within the principal aquifer, such as recharge area, sources of recharge, directions of ground-water flow, both vertically and laterally, and velocity of flow, which in turn, is related to aquifer transmissivity. The second category includes factors related to potential effects and sources of contamination, such as location of the areas of best quality water in the principal aquifer, location of areas of poor quality water in the shallow unconfined aquifer, effects of increased ground-water withdrawals on vertical flow, and relations of public-supply wells and springs to urban areas and hazardous-waste sites.

The primary recharge areas for the principal aquifer are along the mountain fronts on the eastern and, to a lesser degree, western sides of the valley. In these areas, the principal aquifer is unconfined and generally no fine-grained beds are present to impede the downward movement of water from the land surface to the principal aquifer. Contaminants in these areas generally could move directly, and locally rapidly, to the aquifer. If contamination of surface water were to occur in the mountains, or if contamination of ground water were to occur near the contact between the fractured, consolidated rocks of the mountains and basin-fill deposits, water quality in the principal aquifer would almost certainly be affected. In secondary recharge areas, downgradient from the primary areas, confining beds are present but the hydraulic gradient is downward from the shallow unconfined aquifer to the principal aquifer. In these areas, contaminants could move from the land surface to the principal aquifer, but movement would be impeded by the confining beds.

In the areas of large values of transmissivity of the principal aquifer in Salt Lake Valley, generally along the eastern side of the valley, velocities of ground-water movement probably also are large. Contaminants reaching the principal aquifer in these areas would tend to rapidly move away from the recharge areas, downgradient toward the center of the valley, passing through areas where public-supply wells are located.

Where water in the principal aruifer contains less than $500 \mathrm{mg} / \mathrm{L}$ of dissolved solids, generally in the eastern half of the valley, contamination of the principal aquifer would adversely affect the body of ground water of best quality. The areas of water with less than $500 \mathrm{mg} / \mathrm{L}$ dissolved solids in the principal aquifer also are where most of the withdrawals from wells for public supply occur, and contamination in this area would degrade an important source of drinking water for Salt Lake Valley and County.

Areas where the shallow unconfined aquifer contains poorer quality water than the principal aquifer are potential sources of contamination for the principal aquifer. If the hydraulic gradient is currently uf'Nard from the principal aquifer to the shallow unconfined aquifer, contaminants generally will not move down into the principal aquifer. If water levels are drawn down far enough in tho principal aquifer, the gradient could be reversed, and the potential then would exist fcr contaminants to move into the principal aquifer. Areas where model simulations indicate that increases in pumping could $r \in$ verse the hydraulic gradient are specific areas where the potential for water to move from the shallow unconfined aquifer to the princinal aquifer is greater.

Urbanized areas can be sources of contamination to ground water because commercial and industrial activities generate waste materials and fluids which, if improperly disposed of, can enter the groundwater system in leachates or by direct flow. In residential areas, road salts and various 
chemicals applied to lawns and gardens can be dissolved by surface runoff that ultimately becomes recharge to the principal aquifer. If public-supply wells are located in or near recharge areas, near hazardous-waste sites, or in areas where increased pumping could reverse the hydraulic gradient and create the potential for movement of water from the shallow unconfined aquifer to the principal aquifer, water withdrawn from these wells is vulnerable to contamination.

Ground-water contamination is preventable. Careful management of groundwater withdrawals, waste-disposal activities, and land use on recharge areas can help prevent future contamination problems. Tr $\approx$ monitoring and management of groundwater withdrawals and hazardous-waste disposal is critical to preventing groundwater contamination in Salt Lake Valley. Limitations on local ground-water withdrawals could prevent reversals of the hydraulic gradient, and regulation of hazardous-waste disposal could eliminate or at least reduce the potential for introduction of hazardous substances into the ground-water system. Restrictions on certain types of land use in the recharge areas might prevent activities that could contribute contaminants to the ground-water supply. 


\section{REFERENCES CITED}

Arnow, Ted, 1965, Ground water in the Jordan Valley, Salt Lake County, Utah: Utah State Engineer Water Circular No. $1,11 \mathrm{p}$.

Brough, R.C., Griffin, R.D., Richardson, E.A., and Stevens, D.J., 1983, Utah weather guide: Society for Applied Climatology and Brigham Young University, $46 \mathrm{p}$.

Cook, D.R., ed., 1961, Geology of the Bingham mining district and northern Oquirrh Mountains: Utah Geological Society Guidebook to the Geology of Utah, no. 16, $145 \mathrm{p}$.

Environmental Systems Research Institute, 1988, ARC/INFO users guide, volume 1: Environmental Systems Research Institute, Inc., Redlands, CA.

Fenneman, N.M., 1931, Physiography of western United States: McGraw-Hill, New York/London, 534 p.

Gilluly, James, 1932, Geology and ore deposits of the Stockton and Fairfield quadrangles, Utah: U.S. Geological Survey Professional Paper 173, $171 \mathrm{p}$.

Hely, A.G., Mower, R.W., and Harr, C.A., 1971, Water resources of Salt Lake County, Utah: Utah Department of Natural Resources Technical Publication No. 31, 244 p.

Hem, J.D., 1985, Study and interpretation of the chemical quality of natural water (3rd ed.): U.S. Geological Survey Water-Supply Paper 2254, 263 p.

Johnson, Brent, and Jackson, Steven, 1988, Water-use data for public water suppliers and self-supplied industry in Utah 1984, 1985: Utah Department of Natural Resources, Utah Water-Use Report No. $6,131 \mathrm{p}$.
McDonald, M.G., and Harbaugh, A.W., 1984, A modular three-dimensional finite-difference ground-water flow model: U.S. Geological Survey Water Resources Investigations Report 83-875, 528 p.

Miller, R.D., 1980, Surficial geologic map along part of the Wasatch Front, Salt Lake Valley, Utah: U.S. Geo'ogical Survey Miscellaneous Field Studies Map MF-1198, scale 1:100,000, 2 maps and pamphlet.

National Oceanographic and Atmospheric Administration, 1982, Montr'y normals of temperature, precipitatior, and heating and cooling degree days 1951-80: Climatography of the United States No. 81 (by state).

Seiler, R.L., and Waddell, K.M., 1ฐß4, Reconnaissance of the shallow unconfined aquifer in Salt Lake Valley, Utah: U.S. Geological Survey Water-Resources Investigations Report 83-4272, $34 \mathrm{p}$.

University of Utah Research Institute, 1982, Land-use inventory, Salt Lake County: University of Utah Center for Remote Sensing and Cartography, map series for Salt Lake County.

Utah Office of Planning and Buc'get, 1987, Utah data guide: State of Utzh, Office of Planning and Budget, Data Resources Section, v. 6, no. 4, 12 p.

U.S. Environmental Protection Agency, 1987, Secondary maximum contaminant levels (part 1-43, National secondary drinking-water regulations): U.S. Code of Federal Regulations, Titl 340 , Parts 100 to 149 , revised July $1,19^{\wedge} 5$. 
Waddell, K.M., Seiler, R.L., Santini, Melissa, and Solomon, D.K., 1987, Ground-water conditions in Salt Lake Valley with emphasis on 1969-82 water budget and predicted effects of increased withdrawals: Utah Department of Natural Resources Technical Publication No. 87, $69 \mathrm{p}$.
Waddell, K.M., Seiler, R.L., anc' Solomon, D.K., 1987, Chemical qualit' of ground water in Salt Lake Valley, Utah, 1969-85: Utah Department of Natural Resources Technical Publication No. 89, 56 p. 


\section{DEFINITION OF TERMS}

Aquifer.-A formation, group of formations, or part of a formation that contains sufficient saturated permeable material to yield significant quantities of water to wells and sprirgs.

Confining bed.-A body of low-permeability material stratigraphically adjacent to one or more aquifers. In nature, its hydraulic conductivity may range from nearly zero to some value distinctly lower than that of the aquifer.

Digital Line Graph (DLG).-The term adopted by the U.S. Geological Survey National Mapping Division to describe line-graph data that are available in digital form.

Ground water.-Water in the saturated zone that is under a pressure equal to or greater than atmospheric pressure.

Hydraulic conductivity.-The volume of water that will move through a unit cross section of material in unit time under a unit hydraulic gradient. It is determined by the size, shape, and interconnection of the openings in the material and by the viscosity of the fluid.

Hydraulic gradient. - The change in head per unit of distance in a given direction. If the direction is not specified, it is understood to be in the direction in which the maxim sm rate of decrease in head occurs.

Lithology.-The physical characteristics of a rock.

Potentiometric surface.-A surface that represents the static head, i.e., the level to which water will rise in a tightly cased well. This level, generally called hydraulic head, is the sum of the elevation head and the pressure head. Elevation head is a result of the elevation of a given point above a datum plane, and the pressure head is the height of the column of water that rises above the given point.

Primary contaminant levels. - The maximum contaminant level (MCL) for potentially' toxic contaminants where the MCL has no known or anticipated adverse effects on th $ə$ health of individuals and which allows a margin of safety. This is an enforceable standard and has been established to protect the public health.

Recharge.-The movement of water from the land surface to the saturated zone.

Rock.-Any naturally formed, consolidated or unconsolidated material (but not soil) consisting of two or more minerals.

Secondary contaminant levels.-Maximum levels set to protect the aesthetic quality of drinking water (e.g., taste, smell, appearance) based on the National Secondary Drinking-Water Regulations.

Total head.- The height of a column of water above a datum plane. In a ground-water system, it is composed of elevation head and pressure head.

Transmissivity.- The rate at which water is transmitted through a unit width of an aq..ifer under a unit hydraulic gradient. It equals the hydraulic conductivity times the saturated thickness of the aquifer.

Water table.-The surface in an unconfined water body at which the pressure is equal to that of the atmosphere. 
UNITED STATES DEPARTMENT OF THE INTERIOR GEOLOGICAL SURVEY
WATER-RESOURCES INVESTIGATIONS REPORT 90-4I10 1990

\section{EXPLANATION}

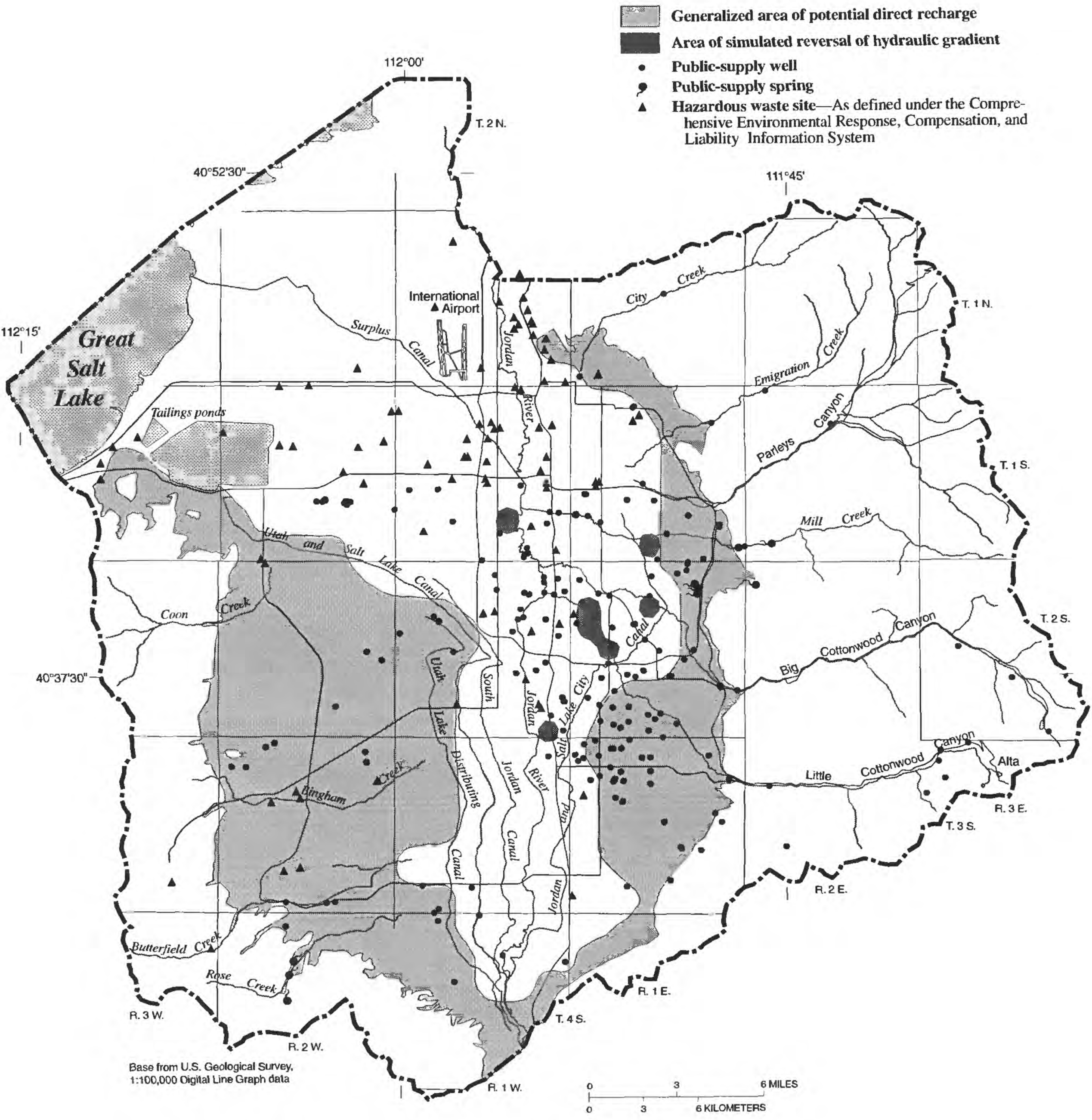

Map showing generalized area of potential direct recharge, simulated areas of reversal of hydraulic gradient due to ground-water withdrawals from the principal aquifer, and locations of public-supply wells, public-supply springs, and hazardous-waste sites in Salt Lake Valley, Utah. 